Eur. J. Clin. Chem. Clin. Biochem.

Vol. 31, 1993, pp. 503-511

(C) 1993 Walter de Gruyter \& Co. Berlin - New York

\title{
A High Performance Liquid Chromatography Method for the Determination of Glycosaminoglycans in Human Blood
}

\author{
By N. Gässler ${ }^{1}, C$. Reißner ${ }^{1}, N$. Janzen ${ }^{1}$, Heike Kähnert ${ }^{2}$ and K. Kleesiek ${ }^{2}$ \\ 1 Institut für Klinische Chemie II der Medizinischen Hochschule Hannover, Zentrallabor im Oststadtkrankenhaus, \\ Hannover \\ 2 Institut für Laboratoriums- und Transfusionsmedizin Herzzentrum Nordrhein-Westfalen, Bad Oeynhausen, \\ Germany
}

(Received February 9/May 6, 1993)

Summary: A method is described for the determination of plasma and serum glycosaminoglycans, which can be used in any laboratory equipped with an HPLC system. It is based on the sequential application of chondroitinases $A C$ and $A B C$ and separation of the resulting disaccharides by high-performance liquid chromatography. All reagents are commercially available. This simple and rapid separation yields an accurate quantification and an exact distribution pattern. The determination of glycosaminoglycan disaccharides is linear between 7 and $7000 \mu \mathrm{mol} / 1$ with coefficients of variation between 3.0 and $7.7 \%$ for serum and between 2 and $14 \%$ for plasma. The recovery of the assay ranged from 93 to $106 \%$ for different concentrations of glycosaminoglycan disaccharides. This HPLC method may therefore be considered as a candidate reference method.

\section{Introduction}

Glycosaminoglycans, which are widely distributed in human tissues and fluids (1), are intimately related to proteoglycan metabolism. In plasma, glycosaminoglycans have a wide range of molecular masses, but a large proportion have relative molecular masses of less than 5000 (2). Various laboratories have demonstrated the presence of glycosaminoglycans in human plasma or serum $(2-5)$. The results indicate that a great quantitative variability may exist among different methods for determination of blood glycosaminoglycans.

Recently we measured the glycosaminoglycan disaccharides from human blood donors, using two different methods for isolation of glycosaminoglycans in plasma and serum. The chromatographic conditions are identical for both methods of glycosaminoglycan isolation.

Significant sex differences in glycosaminoglycan disaccharide composition were found in the present study.

\section{Materials and Methods}

Reagents

Chondroitinase AC (EC 4.2.2.5) ${ }^{1}$ ) of Arthrobacter aurescens (lot E88301) and chondroitinase ABC (EC 4.2.2.4) of Proteus vulgaris (lot E88301) were purchased from Seikagaku Kogyo (Tokyo, Japan). $\alpha$-Mannosidase (EC 3.2.1.24) of Canavalia ensiformis (lot 48F-9545) was from Sigma (St. Louis, USA) and papain (EC 3.4.22.2) from Carica papaya (lot 12385425-75/May 92) from Boehringer Mannheim (Mannheim. Germany).

\section{Calibrator disaccharides}

2-acetamido-2-deoxy-3-O-( $\beta$ - $D$-gluco-4-enepyranosyluronic acid)- $D$-galactose $(\triangle \mathrm{DiOS})$

2-acetamido-2-deoxy-3-O-( $\beta$ - $D$-gluco-4-enepyranosyluronic acid)-4-O-sulpho- $D$-galactose $(\triangle \mathrm{Di} 4 \mathrm{~S})$,

2-acetamido-2-deoxy-3-O-( $\beta$ - $D$-gluco-4-enepyranosyluronic acid)-6-O-sulpho- $D$-galactose $(\triangle \mathrm{Di} 6 \mathrm{~S})$ and

\footnotetext{
1) Enzymes:

Chondroitinase AC (EC 4.2.2.5)

Chondroitinase $\mathrm{ABC}$ (EC 4.2.2.4)

$\alpha$-Mannosidase (EC 3.2.1.24)

Papain (EC 3.4.22.2)
} 
2-acetamido-2-deoxy-3-O-( $\beta$ - $D$-gluco-4-enepyranosyl uronic acid)- $D$-glucose $(\triangle \mathrm{DiHA})$

were available from Seikagaku Kogyo (Tokyo, Japan).

DEAE-Sephacel was from Pharmacia (Freiburg, Germany). All other chemicals were of analytical grade (E. Merck, Darmstadt, Germany).

\section{HPLC equipment}

Separation and measurements were performed with a Jasco flow pump Model 880-PU (Techlab, Erkerode, Germany), a spectrophotometer SP-4 (Gynkotek, Gering, Germany), an autosampler WISP ${ }^{\mathrm{TM}}$ Model 710B (Millipore, Königstein, Germany) and a Philips CM 9043 AT Computer (Philips, Hamburg, Germany) with an Axiom 717 chromatography data system (LDC Analytical, Hasselroth, Germany). A Nucleosil SB 5 anion exhange column $(4.6 \times 125 \mathrm{~mm}, 5 \mu \mathrm{m}$ particles $)$ connected with a Hypersil ODS RP-C 18 reversed phase column (4.6 $\times 125 \mathrm{~mm}, 5 \mu \mathrm{m}$ particles) was used to separate sulphated glycosaminoglycan disaccharides, and a Hypersil APS weak anion exchange column $(4.6 \times 250 \mathrm{~mm}, 5 \mu \mathrm{m}$ particles $)$ connected with a Hypersil ODS RP-C18 column $(4.6 \times 15 \mathrm{~mm}$, $5 \mu \mathrm{m}$ particles) was used to separate non-sulphated glycosaminoglycan disaccharides. Columns were from Shandon/VDS (Optilab Chromat. Technic, Techlab, Erkerode, Germany). Detection was by UV absorbance at $232 \mathrm{~nm}$.

\section{Chromatographic conditions}

A filtered (0.4 $\mu \mathrm{m}$, Millipore, Neu-Isenburg, Germany) and helium-saturated mobile phase of $0.22 \mathrm{~mol} / \mathrm{l}$ sodium chloride was used for separation of sulphated disaccharides. The flow rate was $0.8 \mathrm{ml} / \mathrm{min}$. Non-sulphated components were separated with the same flow rate by the use of a filtered and oxygenpoor mobile phase of $2.5 \mathrm{mmol} / \mathrm{l}$ disodium hydrogen phosphate, pH 3.0 containing $15 \mathrm{mmol} / \mathrm{l}$ sodium chloride.

Disaccharides were injected in quantities of 0.07 to $70 \mathrm{nmol}$ dissolved in $10 \mu \mathrm{l}$ water $(7-7000 \mu \mathrm{mol} / \mathrm{l})$. Solutions of commercially available calibrators were used for quantification (external calibrator method).

\section{Sample preparation}

Plasma samples were obtained from about $10 \mathrm{ml}$ of whole blood which were collected in a Monovette ${ }^{\circledR}$ (Sarstedt, Nümbrecht, Germany) tube containing $0.05 \mathrm{mmol} / \mathrm{l}$ EDTA, then centrifuged at $3000 \mathrm{~min}^{-1}(2000 \mathrm{~g})$ for 10 minutes at $4^{\circ} \mathrm{C}$.

Serum samples were collected in Monovette ${ }^{\circledR}$ (Sarstedt, Nümbrecht, Germany) tubes containing Kaolin. After clotting for $1 / 2$ to 1 hour at room temperature, samples wer centrifuged under the same conditions. Specimens were stored at $4^{\circ} \mathrm{C}$ for analysis within one day. At $-20^{\circ} \mathrm{C}$ specimens could be stored for several months.

Serum supernatants were digested for 16 hours at $60^{\circ} \mathrm{C}$ with $300 \mu \mathrm{l}$ papain solution ( $3 \mathrm{MU} / \mathrm{l}$ cysteine buffer) in $10 \mathrm{ml}$ glass tubes containing $4.5 \mathrm{ml}$ cysteine buffer $(0.011 \mathrm{~mol} / \mathrm{l}$ cysteine, $0.045 \mathrm{~mol} / \mathrm{l}$ disodium EDTA, $0.045 \mathrm{~mol} / \mathrm{l}$ potassium dihydrogen phosphate, $0.067 \mathrm{~mol} / 1$ dipotassium hydrogen phosphate, $\mathrm{pH}$ 5.8). Papain ( $150 \mu \mathrm{l}$ containing $3 \mathrm{MU} / \mathrm{l}$ buffer) and cysteine $(0.05 \mathrm{~mol})$ were then added and digestion continued for a further $4 \mathrm{~h}$. The cholesterol ester content was diminished by vigorously extracting each sample with $3.0 \mathrm{ml}$ chloroform.
Peptides were precipitated by storage overnight after the addition of $2 \mathrm{ml}$ trichloroacetic acid $(0.61 \mathrm{~mol} / \mathrm{l})$. The solutions were centrifuged $\left(5000 \mathrm{~min}^{-1}, 20 \mathrm{~min}\right.$ at $\left.4^{\circ} \mathrm{C}\right)$ and the recovered supernatants were washed three times with $5 \mathrm{ml} n$-butanol. Remaining aqueous phases were evaporated for 5 minutes to remove the $n$-butanol. One millilitre equilibration buffer $(0.15$ $\mathrm{mol} / \mathrm{l}$ lithium chloride in $0.02 \mathrm{~mol} / \mathrm{l} \mathrm{Tris} / \mathrm{HCl}, \mathrm{pH}$ 8.6) was added and the solution applied to columns $(4.0 \times 1.0 \mathrm{~cm} \mathrm{I.D.)}$ packed with DEAE-Sephacel. After washing two times with $5 \mathrm{ml}$ equilibration buffer, glycosaminoglycans were eluted with $8.0 \mathrm{ml}$ of $2.0 \mathrm{~mol} / 1$ lithium chloride containing $0.02 \mathrm{~mol} / 1 \mathrm{Tris} /$ $\mathrm{HCl}, \mathrm{pH}$ 8.6. The eluate was pooled, evaporated to near dryness, and glycosaminoglycans were precipitated overnight after addition of $5 \mu \mathrm{l}$ of saturated sodium acetate solution and $12 \mathrm{ml}$ ethanol at $4^{\circ} \mathrm{C}$. The precipitates were centrifuged $\left(5000 \mathrm{~min}^{-1}\right.$, $20 \mathrm{~min}$ at $4^{\circ} \mathrm{C}$ ) and dryed. After dissolving in $1.0 \mathrm{ml}$ double distilled water, the samples were ready for enzymatic digestion.

Plasma samples $(5.0 \mathrm{ml})$ were applied to columns $(4.0 \times 1.0$ $\mathrm{cm}$ I. D.) packed with DEAE-Sephacel and washed with $10 \mathrm{ml}$ of a solution $(0.15 \mathrm{~mol} / \mathrm{l}$ sodium chloride in $0.02 \mathrm{~mol} / 1 \mathrm{Tris} /$ $\mathrm{HCl}, \mathrm{pH}$ 8.6). The glycosaminoglycans were eluted with $10 \mathrm{ml}$ of $2.0 \mathrm{~mol} / \mathrm{l}$ lithium chloride containing $0.02 \mathrm{~mol} / 1 \mathrm{Tris} / \mathrm{HCl}$, $\mathrm{pH} 8.6$, desalted and concentrated to $1.0 \mathrm{ml}$ by ultrafiltration (membrane $1000 \mathrm{~K}, 0.27 \mathrm{ml} / \mathrm{min}$ ). Buffer $(1.0 \mathrm{ml}, 0.1 \mathrm{~mol} / \mathrm{l}$ trisodium citrate, $\mathrm{pH} 4.5$ ) and $10 \mu \mathrm{l} \alpha$-mannosidase (450 U/l buffer) were added to the concentrates, which were digested for 18 hours at $37^{\circ} \mathrm{C}$. The solutions were centrifuged $\left(17000 \mathrm{~min}^{-1}\right.$, $30 \mathrm{~min}$ at $8^{\circ} \mathrm{C}$ ) and the supernates again applied to the same DEAE-Sephacel columns. After washing the columns with 2.5 $\mathrm{ml} 0.1 \mathrm{~mol} / 1$ sodium chloride in $0.02 \mathrm{~mol} / 1 \mathrm{Tris} / \mathrm{HCl}, \mathrm{pH} 8.6$, the glycosaminoglycans were eluted with $2.0 \mathrm{ml}$ of $2.0 \mathrm{~mol} / \mathrm{l}$ lithium chloride containing $0.02 \mathrm{~mol} / \mathrm{l}$ Tris/ $\mathrm{HCl}, \mathrm{pH}$ 8.6. The eluates were desalted by ultrafiltration (membrane $1000 \mathrm{~K}, 0.16$ $\mathrm{ml} / \mathrm{min}$ ) and concentrated to $600-700 \mu \mathrm{l}$. After adjusting the volume of each eluate to $1.0 \mathrm{ml}$ by the addition of double distilled water, the samples were ready for enzymatic digestion.

The aqueous solutions of glycosaminoglycans were analysed by the uronic acid method of Kosakai \& Yosizawa (6), and by the direct photometric method of Farndale (7) for sulphated glycosaminoglycans, using 1,9-dimethylmethylene blue.

The method used for sequential digestion of glycosaminoglycans with chondroitinase $A C$ and chondroitinase $A B C$ has been described by Gurr et al. (8). Each enzymatic degradation step was followed by separation of products from the undigested glycosaminoglycans by precipating the undigested polysaccharides with ethanol. The digested products, disaccharides of hyaluronan, non-sulphated chondroitin, chondroitin sulphate, non-sulphated dermatan and dermatan sulphate, were concentrated to dryness to rotary evaporation and finally dissolved in $200 \mu$ l double distilled water. Ten microlitres of sample were injected for the high performance liquid chromatographic assay.

\section{Specimens}

Blood was obtained in the morning from 30 apparently healthy volunteers and 78 healthy blood donors ( 53 men and 55 female, aged 18 to 60 years). All were in good nutritional state; none took drugs.

\section{Calibration}

Solutions of pure disaccharides were used for calibration (external standard method). Losses of sample preparation were quantified with glycosaminoglycan ipolysaccharide calibrators (internal standard method).

All analyses were performed in duplicate. 


\section{Results and Discussion}

High performance liquid chromatography of the disaccharides

\section{Effect of ion exchanger and ionic strength on the elution pattern}

Nucleosil SB is a potent ion exchanger bonded to silica gel, with a functional quaternary ammonium group. Aqueous sodium chloride solutions were used to separate a calibrator solution of the pure sulphated glycosaminoglycan disaccharides. Good separation of sulphated disaccharides was obtained in serum samples, but in plasma samples no satisfactory separation was achieved. Further separation on a Hypersil ODS C18 reversed phase column allowed separation of plasma components and of the disaccharides chondroitin-6-sulphate, chondroitin-4-sulphate, dermatan6-sulphate, and dermatan-4-sulphate. The best results were obtained with $0.22 \mathrm{~mol} / \mathrm{l}$ sodium chloride solutions and a flow rate of $0.8 \mathrm{ml} / \mathrm{min}$ (fig. 1).

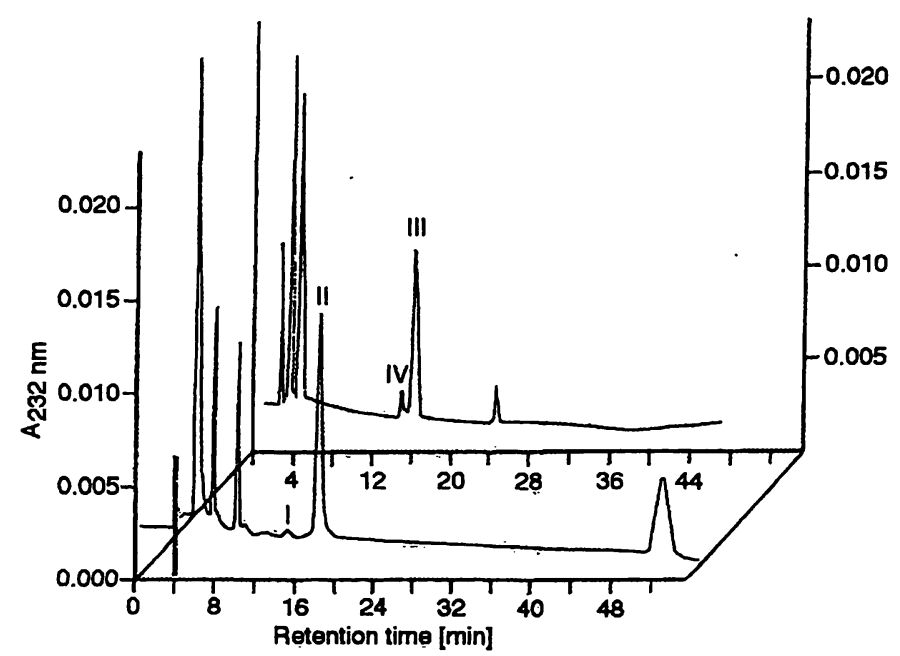

Fig. 1. HPLC chromatograms of glycosaminoglycan disaccharides in human plasma and serum (same chromatograms but shorter retention times).

Sulphated glycosaminoglycans in front: chondroitin-4sulphate (II) and chondroitin-6-sulphate (I) disaccharides.

Non-sulphated glycosaminoglycans (back): hyaluronan (IV) and chondroitin (III) disaccharides.

Hypersil APS is a weak potent ion exchanger based on a primary ammonium salt. Buffered sodium phosphate solutions ( $\mathrm{pH} 4.5$ to 6.0 ) were used in preliminary experiments to separate a calibrator solution of the pure non-sulphated glycosaminoglycan disaccharides and serum samples. With an additional Hypersil ODS C18 reversed-phase column, plasma samples were separated satisfactorily. However, plasma solutions showed a double peak for the two anomeric forms of the hyaluronan disaccharide, both in pure calibrator solutions and in plasma solutions (for further details see Hjerpe et al. 1982). Variation of ionic strength, concentration of hydrogen ions and additionally salt concentrations of the eluent were studied. Chromatography was finally performed with a solution containing disodium hydrogen phosphate $(2.5$ $\mathrm{mmol} / \mathrm{l}, \mathrm{pH} 3.0)$ and sodium chloride $(15 \mathrm{mmol} / \mathrm{l})$ with a flow rate of $0.8 \mathrm{ml} / \mathrm{min}$ (fig. 1).

\section{Linearity and recovery}

In order to determine the range of linearity, chromatography was performed using solutions containing mixtures of the pure disaccharides in concentrations between 7 and $7000 \mu \mathrm{mol} / \mathrm{l}(0.07$ and $70 \mathrm{nmol}$ per injection). A linear increase in the signal accompanied the increase in sample concentration for the glycosaminoglycan disaccharides over the entire range (fig. 2). Linear regression analyses of the results gave

$\mathrm{y}=-0.102+0.934 \mathrm{x}$ with a correlation coefficient of 0.999 for 2-acetamido-2-deoxy-3-( $\beta-D$-gluco4-enepyranosyluronic acid)-4-O-sulpho- $D$-galactose $(\Delta \mathrm{Di} 4 \mathrm{~S})$;

$\mathrm{y}=0.958+0.924 \mathrm{x}$ with a correlation coefficient of 0.999 for 2-acetamido-2-deoxy-3-( $\beta$ - $D$-gluco4-enepyranosyluronic acid)-6-O-sulpho- $D$-galactose $(\Delta \mathrm{Di} 6 \mathrm{~S})$

$\mathrm{y}=1.138+1.054 \mathrm{x}$ with a correlation coefficient of 0.999 for 2-acetamido-2-deoxy-3-( $\beta$ - $D$-gluco-4-enepyranosyluronic acid)- $D$-galactose $(\Delta \mathrm{Di} 0 \mathrm{~S})$; and

$\mathrm{y}=1.618+1.127 \mathrm{x}$ with a correlation coefficient of 0.999 for 2-acetamido-2-deoxy-3-( $\beta$ - $D$-gluco-4-enepyranosyluronic acid)- $D$-glucose $(\Delta \mathrm{DiHA})$.

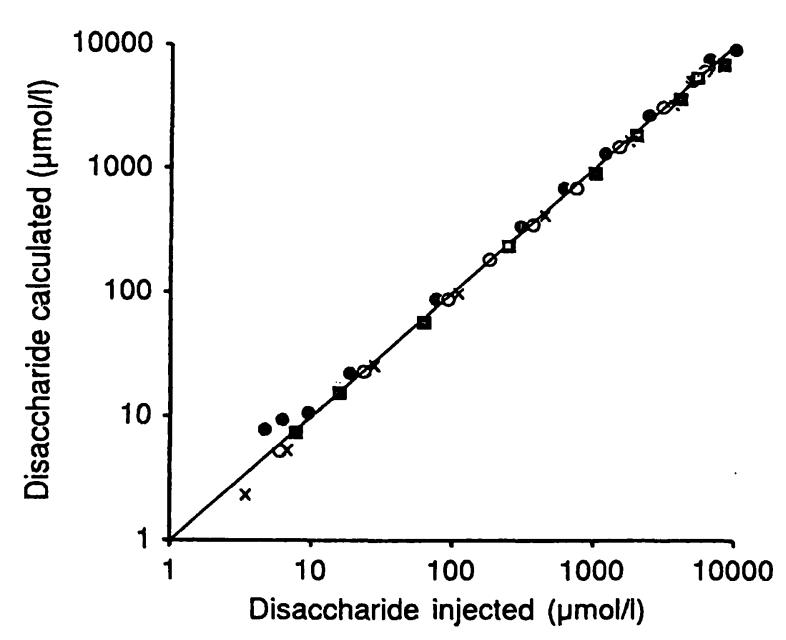

Fig. 2. Linearity of detector response: peak area vs. sample concentration.

Hyaluronan ( $(\bullet)$, chondroitin $(0)$, chondroitin-4-sulphate $(x)$, chondroitin-6-sulphate (a) disaccharide. 
Tab. 1. Recovery of glycosaminoglycan disaccharides in different concentrations.

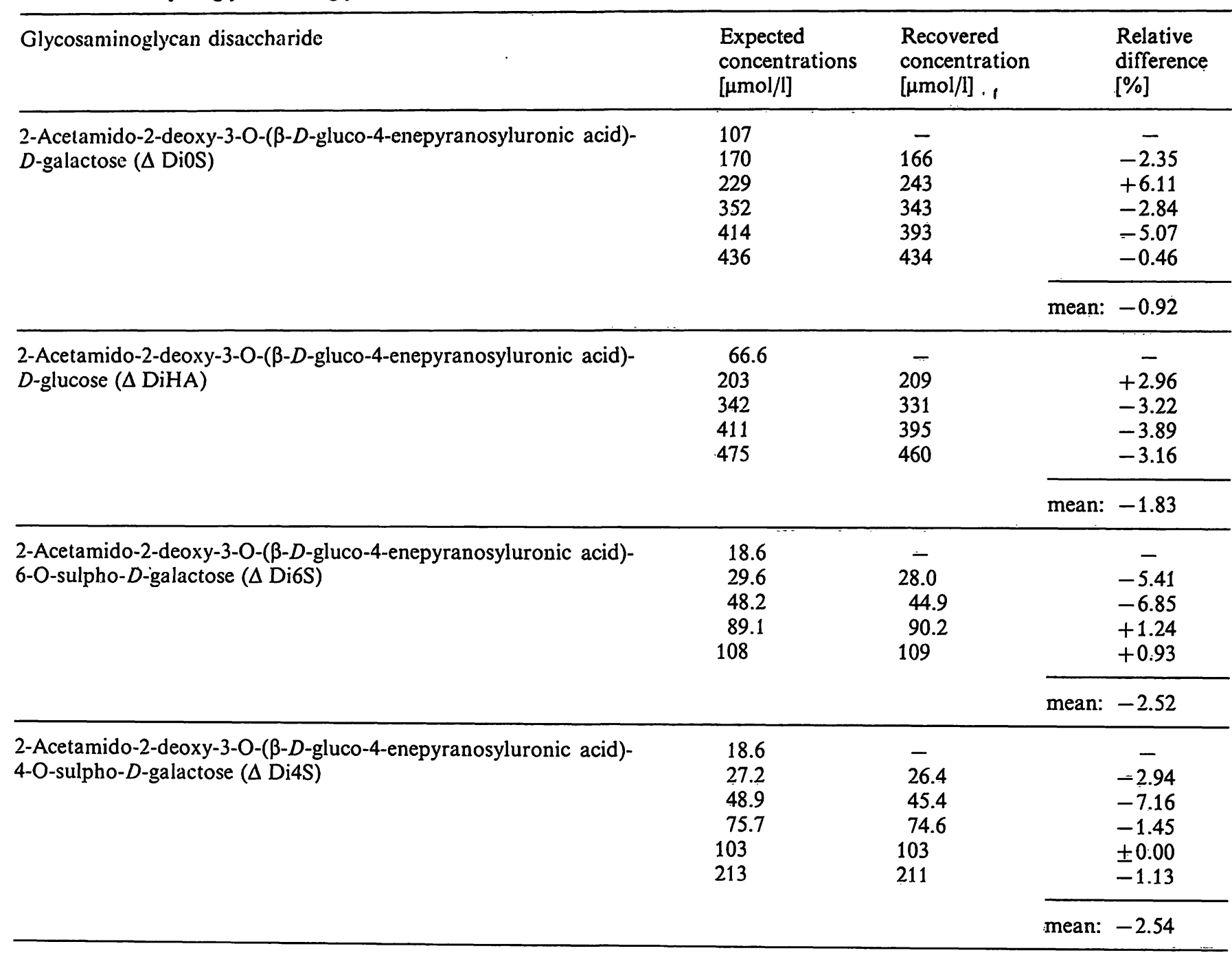

To investigate the recovery of the method, various concentrations of pure sulphated and non-sulphated disaccharides were added to blood samples. Recovery ranged

from 92.8 to $100 \%$ for $\Delta \mathrm{Di} 4 \mathrm{~S}$,

from 93.1 to $101 \%$ for $\Delta$ Di6S,

from 96.1 to $103 \%$ for $\triangle \mathrm{DiHA}$ and

from 94.9 to $106 \%$ for $\Delta$ Di0S (tab. 1, fig. 3).

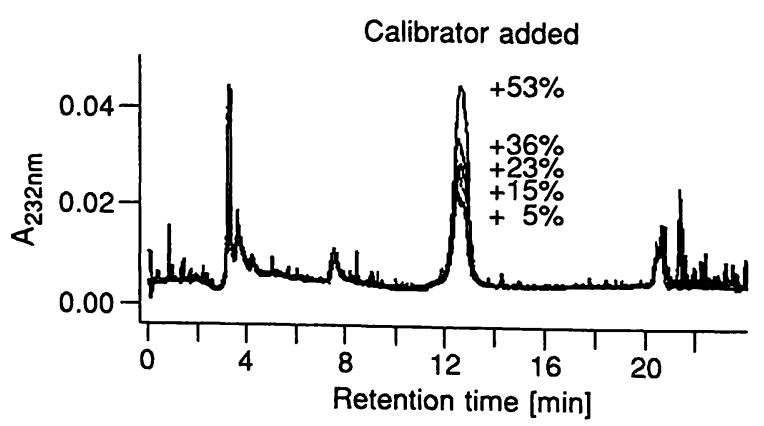

Fig. 3. Recovery of chondroitin disaccharide. Chromatograms of increasing quantities of added calibrator are superimposed.
For comparison, glucuronic acid added to blood samples showed a recovery of $92.3 \%$ with the assay of Kosaki \& Yosizawa, while added polymeric chondroitin sulphate showed a recovery of $89.5 \%$ with the assay of Farndale et al. These findings imply that the losses are accounted for in the preparation steps of plasma/serum and not in the enzymatic digestion steps.

The sensitivity of the method when defined as a signal to noise ratio $\geq 3$ is at least $3.0 \mu \mathrm{mol} / 1$ serum or plasma ( $0.1 \mathrm{nmol}$ per injection). This value is in accordance with other methods $(14,15)$.

\section{Precision}

The total imprecision of the method was determined for pure calibrators, and for plasma and serum samples. Coefficients of variation ranging from 1.3 to $2.3 \%$ for non-sulphated calibrators ( $\triangle \mathrm{DiHA}$ and $\Delta$ DiOS) and from 1.5 to $2.1 \%$ for sulphated calibrators $(\Delta \mathrm{Di} 4 \mathrm{~S}$ and $\Delta \mathrm{Di} 6 \mathrm{~S})$ were calculated within a series of 18 and 20 chromatograms, respectively (con- 
centrations between 67 and $238 \mu \mathrm{mol} / \mathrm{l}$; data not shown). For plasma/serum samples the coefficients of variation did not exceed $5.4 \%$ for sulphated glycosaminoglycan disaccharides $(n=14$, resp. 20; tab. 2).

For determination of the inter-assay coefficient of variation replicate chromatograms were run on 7 or 10 consecutive days (tab. 3 ). The coefficients of variation ranged between 1.1 and $4.7 \%$ for non-sulphated calibrators, up to $6.8 \%$ for sulphated calibrators, up to $7.6 \%$ for non-sulphated glycosaminoglycan disaccharides in plasma/serum samples and between 7.1 and $17 \%$ for sulphated glycosaminoglycan disaccharides in blood samples. No recalibration was carried out during these experiments, but the columns were changed after approximately 150 runs. The high coefficients of variation within a series for $\triangle \mathrm{DiHA}$ and from day to day for $\Delta \mathrm{Di} 6 \mathrm{~S}$ can be explained by the low concentrations of these disaccharides in plasma samples. Apart from these exceptions, coefficients of variation do not exceed $7.9 \%$.

The total imprecision of the method, within-run imprescision and day-to-day variation are equal to or less than those reported for other HPLC assays in plasma/serum (15).
Determination of glycosaminoglycan distribution pattern

For the determination of glycosaminoglycan distribution patterns a technique has been described in which hyaluronan, chondroitin, chondroitin sulphate, dermatan and finally dermatan sulphate are digested in sequential steps using papain/mannosidase, chondroitinase $\mathrm{AC}$ and chondroitinase $\mathrm{ABC}$, followed by high performance liquid chromatographic analysis of the metabolites. Firstly, interfering plasma/serum components must be removed by column chromatography. Up to $30 \%$ of serum proteins were bound on DEAE-Sephacel, but more than $98 \%$ of plasma proteins were eluted together with plasma glycosaminoglycans. Samples were then desalted by ultrafiltration or precipitated with ethanol. This step was necessary for accurate and quantitative determination of glycosaminoglycans. Four or five working days were required to determine the glycosaminoglycans and their distribution pattern. The proteolysis with papain/mannosidase was time-consuming but necessary. After this enzymatic digestion, all glycosaminoglycans were detected in the supernates, so that blood samples could easily be processed in a few days and then analysed overnight.

Tab. 2. Reproducibility of high-performance liquid chromatographic analysis in plasma and serum. Coefficients of variation within a series.

\begin{tabular}{|c|c|c|c|c|}
\hline Glycosaminoglycan disaccharides & Material & $\begin{array}{l}\text { Number of } \\
\text { measurements }\end{array}$ & $\begin{array}{l}\text { Concentration } \\
{[\mu \mathrm{mol} / \mathrm{l}]}\end{array}$ & $\begin{array}{l}\text { Coefficient of } \\
\text { variation }[\%]\end{array}$ \\
\hline $\begin{array}{l}\text { 2-Acetamido-2-deoxy-3-O-( } \beta \text { - } D \text {-gluco-4-enepyranosyl- } \\
\text { uronic acid)- } D \text {-glucose }(\Delta \text { DiHA) }\end{array}$ & $\begin{array}{l}\text { plasma } \\
\text { serum }\end{array}$ & $\begin{array}{l}18 \\
20\end{array}$ & $\begin{array}{l}7.00 \pm 0.98 \\
8.60 \pm 0.27\end{array}$ & $\begin{array}{c}14.0 \\
3.56\end{array}$ \\
\hline $\begin{array}{l}\text { 2-Acetamido-2-deoxy-3-O-( } \beta-D \text {-gluco-4-enepyranosyl- } \\
\text { uronic acid)- } D \text {-galactose ( } \Delta \mathrm{Di} 0 \mathrm{~S})\end{array}$ & $\begin{array}{l}\text { plasma } \\
\text { serum }\end{array}$ & $\begin{array}{l}18 \\
20\end{array}$ & $\begin{array}{r}110 \pm 4.05 \\
9.70 \pm 0.29\end{array}$ & $\begin{array}{l}3.68 \\
3.03\end{array}$ \\
\hline $\begin{array}{l}\text { 2-Acetamido-2-deoxy-3-O-( } \beta \text { - } D \text {-gluco-4-enepyranosyl- } \\
\text { uronic acid)-4-O-sulpho- } D \text {-galactose }(\Delta \mathrm{Di} 4 S)\end{array}$ & $\begin{array}{l}\text { plasma } \\
\text { serum }\end{array}$ & $\begin{array}{l}14 \\
20\end{array}$ & $\begin{array}{r}169 \pm 4.43 \\
7.90 \pm 0.30\end{array}$ & $\begin{array}{l}2.62 \\
4.02\end{array}$ \\
\hline $\begin{array}{l}\text { 2-Acetamido-2-deoxy-3-O-( } \beta \text { - } D \text {-gluco-4-enepyranosyl- } \\
\text { uronic acid)-6-O-sulpho- } D \text {-galactose }(\Delta \mathrm{Di} S \mathrm{~S})\end{array}$ & $\begin{array}{l}\text { plasma } \\
\text { serum }\end{array}$ & $\begin{array}{l}14 \\
20\end{array}$ & $\begin{array}{l}5.00 \pm 0.30 \\
9.32 \pm 0.32\end{array}$ & $\begin{array}{l}5.38 \\
3.62\end{array}$ \\
\hline
\end{tabular}

Tab. 3. Reproducibility of high-performance liquid chromatographic analysis in plasma and serum. Coefficients of variation between the series (from day to day).

\begin{tabular}{|c|c|c|c|c|}
\hline Glycosaminoglycan disaccharides & Material & $\begin{array}{l}\text { Number of } \\
\text { measurements }\end{array}$ & $\begin{array}{l}\text { Concentration } \\
{[\mu \mathrm{mol} / 1]}\end{array}$ & $\begin{array}{l}\text { Coefficient of } \\
\text { variation [\%] }\end{array}$ \\
\hline $\begin{array}{l}\text { 2-Acetamido-2-deoxy-3-O-( } \beta \text { - } D \text {-gluco-4-enepyranosyl- } \\
\text { uronic acid)- } D \text {-glucose }(\Delta \mathrm{DiHA})\end{array}$ & $\begin{array}{l}\text { plasma } \\
\text { serum }\end{array}$ & $\begin{array}{r}7 \\
10\end{array}$ & $\begin{array}{l}7.00 \pm 0.48 \\
8.62 \pm 0.61\end{array}$ & $\begin{array}{l}6.86 \\
7.61\end{array}$ \\
\hline $\begin{array}{l}\text { 2-Acetamido-2-deoxy-3-O-( } \beta-D \text {-gluco-4-enepyranosyl- } \\
\text { uronic acid)- } D \text {-galactose }(\Delta \mathrm{Di} 0 \mathrm{~S})\end{array}$ & $\begin{array}{l}\text { plasma } \\
\text { serum }\end{array}$ & $\begin{array}{r}7 \\
10\end{array}$ & $\begin{array}{r}110 \pm 7.30 \\
9.73 \pm 0.51\end{array}$ & $\begin{array}{l}6.64 \\
5.06\end{array}$ \\
\hline $\begin{array}{l}\text { 2-Acetamido-2-deoxy-3-O-( } \beta \text { - } D \text {-gluco-4-enepyranosyl- } \\
\text { uronic acid)-4-O-sulpho- } D \text {-galactose }(\Delta \mathrm{Di} 4 \mathrm{~S})\end{array}$ & $\begin{array}{l}\text { plasma } \\
\text { serum }\end{array}$ & $\begin{array}{r}7 \\
10\end{array}$ & $\begin{aligned} 169 & \pm 13.3 \\
7.90 & \pm 0.56\end{aligned}$ & $\begin{array}{l}7.87 \\
7.07\end{array}$ \\
\hline $\begin{array}{l}\text { 2-Acetamido-2-deoxy-3-O-( } \beta \text { - } D \text {-gluco-4-enepyranosyl- } \\
\text { uronic acid)-6-O-sulpho- } D \text {-galactose ( } \triangle \mathrm{Di} 6 \mathrm{~S})\end{array}$ & $\begin{array}{l}\text { plasma } \\
\text { serum }\end{array}$ & $\begin{array}{r}7 \\
10\end{array}$ & $\begin{array}{l}5.00 \pm 0.85 \\
9.32 \pm 0.59\end{array}$ & $\begin{array}{l}17.0 \\
6.97\end{array}$ \\
\hline
\end{tabular}


The chondroitin and chondroitin-4-sulphate disaccha- phate and dermatan were detectable (tab. 4). Different rides account for up to $92 \%$ of the total glycosami- methods $(2,3,5,10)$ yield similar distribution patterns noglycans in serum; only traces of dermatan-6-sul- of disaccharides.

Tab. 4. Glycosaminoglycan disaccharide concentrations, analysed in serum

a) males $(\mathrm{n}=53)$

\begin{tabular}{|c|c|c|c|c|c|c|c|c|}
\hline \multicolumn{9}{|c|}{ Glycosaminoglycan disaccharides $[\mu \mathrm{mol} / \mathrm{l}]$} \\
\hline Patients & Hyaluronan & Chondroitin & $\begin{array}{l}\text { Chondroitin- } \\
\text { 4-sulphate }\end{array}$ & $\begin{array}{l}\text { Chondroitin- } \\
\text { 6-sulphate }\end{array}$ & Dermatan & $\begin{array}{l}\text { Dermatan- } \\
\text { 4-sulphate }\end{array}$ & $\begin{array}{l}\text { Dermatan- } \\
\text { 6-sulphate }\end{array}$ & Sum \\
\hline 1 & 0.39 & 5.14 & 0.68 & 0.08 & 0.10 & 0.51 & 0.00 & 6.90 \\
\hline 2 & 0.71 & 4.84 & 1.15 & 1.16 & 0.11 & 0.61 & 0.00 & 8.58 \\
\hline 3 & 0.00 & 5.63 & 4.78 & 0.20 & 0.00 & 1.61 & 0.02 & 12.24 \\
\hline 4 & 0.08 & 1.48 & 1.30 & 0.21 & 0.00 & 1.15 & 0.22 & 4.44 \\
\hline 5 & 0.17 & 4.64 & 2.46 & 0.00 & 0.00 & 0.83 & 0.00 & 8.10 \\
\hline 6 & 1.20 & 3.05 & 5.09 & 0.70 & 0.19 & 0.52 & 0.00 & 10.75 \\
\hline 7 & 0.50 & 7.18 & 0.30 & 1.30 & 0.38 & 0.94 & 0.09 & 10.69 \\
\hline 8 & 0.19 & 5.30 & 4.32 & 0.25 & 0.00 & 1.90 & 0.00 & 11.96 \\
\hline 9 & $0: 28$ & 7.09 & 5.07 & 0.49 & 0.37 & 1.26 & 0.00 & 14.56 \\
\hline 10 & 0.13 & 3.66 & 2.19 & 0.00 & 0.00 & 0.63 & 0.00 & 6.61 \\
\hline 11 & 0.00 & 4.38 & 6.32 & 0.13 & 0.00 & 0.00 & 0.00 & 10.83 \\
\hline 12 & 0.00 & 4.25 & 4.55 & 0.18 & 0.00 & 0.00 & 0.00 & 8.98 \\
\hline 13 & 0.27 & 3.63 & 4.77 & 0.23 & 0.00 & 0.00 & 0.00 & 8.90 \\
\hline 14 & 0.51 & 1.00 & 1.05 & 0.07 & 0.00 & 0.00 & 0.00 & 2.63 \\
\hline 15 & 0.00 & 1.98 & 1.99 & 0.07 & 0.00 & 0.00 & 0.00 & 4.04 \\
\hline 16 & 0.52 & 8.08 & 0.88 & 0.00 & 0.09 & 0.82 & 0.00 & 10.39 \\
\hline 17 & 0.00 & 5.51 & 0.68 & 1.00 & 0.11 & 0.89 & 0.00 & 8.19 \\
\hline 18 & 0.24 & 5.20 & 5.11 & 0.17 & 0.00 & 1.27 & 0.00 & 11.99 \\
\hline 19 & 0.00 & 3.53 & 1.25 & 0.14 & 0.00 & 1.42 & 0.00 & 6.34 \\
\hline 20 & 0.00 & 8.52 & 4.22 & 0.34 & 0.00 & 0.86 & 0.02 & 13.96 \\
\hline 21 & 0.39 & 5.14 & 0.68 & 0.08 & 0.10 & 0.51 & 0.00 & 6.90 \\
\hline 22 & 0.71 & 4.84 & 1.15 & 1.16 & 0.11 & 0.61 & 0.00 & 8.58 \\
\hline 23 & 0.00 & 5.63 & 4.78 & 0.20 & 0.00 & 1.61 & 0.02 & 12.24 \\
\hline 24 & 0.08 & 1.48 & 1.30 & 0.21 & 0.00 & 1.15 & 0.22 & 4.44 \\
\hline 25 & 0.17 & 4.64 & 2.46 & 0.09 & 0.00 & 0.83 & 0.00 & 8.19 \\
\hline 26 & 0.50 & 7.18 & 0.30 & 1.30 & 0.38 & 0.94 & 0.09 & 10.69 \\
\hline 27 & 0.19 & 5.30 & 4.32 & 0.25 & 0.00 & 1.90 & 0.00 & 11.96 \\
\hline 28 & 0.28 & 7.09 & 5.07 & 0.49 & 0.37 & 1.26 & 0.00 & 14.56 \\
\hline 29 & 0.13 & 3.66 & 2.19 & 0.00 & 0.00 & 0.63 & 0.00 & 6.61 \\
\hline 30 & 0.17 & 9.19 & 1.34 & 0.20 & 0.11 & 0.70 & 0.00 & 11.71 \\
\hline 31 & 0.66 & 6.40 & 1.10 & 0.66 & 0.27 & 0.72 & 0.00 & 9.81 \\
\hline 32 & 0.55 & 2.94 & 3.01 & 0.12 & 0.29 & 0.72 & 0.01 & 7.64 \\
\hline 33 & 0.69 & 6.46 & 4.96 & 0.05 & 0.00 & 1.28 & 0.00 & 13.44 \\
\hline 34 & 0.00 & 4.72 & 2.52 & 0.00 & 0.00 & 1.39 & 0.00 & 8.63 \\
\hline 35 & 0.06 & 3.92 & 0.60 & 0.18 & 0.20 & 1.07 & 0.00 & 6.03 \\
\hline 36 & 0.28 & 5.71 & 2.01 & 1.50 & 0.22 & 0.86 & 0.00 & 10.58 \\
\hline 37 & 0.06 & 4.04 & 2.81 & 0.20 & 0.00 & 1.34 & 0.01 & 8.46 \\
\hline 38 & 0.00 & 3.44 & 2.49 & 0.00 & 0.00 & 0.73 & 0.00 & 6.66 \\
\hline 39 & 0.17 & 3.56 & 0.80 & 0.05 & 0.22 & 0.67 & 0.00 & 5.47 \\
\hline 40 & 0.62 & 5.06 & 0.09 & 0.54 & 0.19 & 0.75 & 0.07 & 7.32 \\
\hline 41 & 0.00 & 1.38 & 2.02 & 0.24 & 0.00 & 1.33 & 0.00 & 4.97 \\
\hline 42 & 0.27 & 9.97 & 6.16 & 0.36 & 0.00 & 1.18 & 0.00 & 17.94 \\
\hline 43 & 0.15 & 2.38 & 1.96 & 0.00 & 0.00 & 0.89 & 0.00 & 5.38 \\
\hline 44 & 0.05 & 4.39 & 0.56 & 0.00 & 0.22 & 1.06 & 0.00 & 6.28 \\
\hline 45 & 0.33 & 5.66 & 0.77 & 0.13 & 0.05 & 0.70 & 0.00 & 7.64 \\
\hline 46 & 0.02 & 7.08 & 2.87 & 0.09 & 0.00 & 1.39 & 0.18 & 11.63 \\
\hline 47 & 0.25 & 11.01 & 6.13 & 0.55 & 0.26 & 1.51 & 0.21 & 19.92 \\
\hline 48 & 0.10 & 4.05 & 2.39 & 0.00 & 0.00 & 0.79 & 0.00 & 7.33 \\
\hline 49 & 0.26 & 9.67 & 1.37 & 0.10 & 0.15 & 0.86 & 0.01 & 12.42 \\
\hline 50 & 0.49 & 3.00 & 0.62 & 0.02 & 0.15 & 0.90 & 0.00 & 5.18 \\
\hline 51 & 0.38 & 1.89 & 2.14 & 0.00 & 0.00 & 1.10 & 0.00 & 5.51 \\
\hline 52 & 0.37 & 11.57 & 6.11 & 0.30 & 0.54 & 1.54 & 0.12 & 20.55 \\
\hline 53 & 0.39 & 3.74 & 3.69 & 0.00 & 0.00 & 0.67 & 0.00 & 8.49 \\
\hline$\overline{\mathbf{x}}$ & 0.263 & 5.10 & 2.62 & 0.298 & 0.098 & 0.921 & 0.024 & 9.33 \\
\hline $\mathbf{S}$ & 0.251 & 2.39 & 1.84 & 0.380 & 0.134 & 0.453 & 0.058 & \\
\hline
\end{tabular}


Our data showed significant differences $(p<0.005$, women. There was no detectable age-dependency, but Wilcoxon test for pair differences) between the main subjects younger than 18 and older than 60 were not glycosaminoglycan disaccharide values in men and included in the study.

b) females $(n=55)$

\begin{tabular}{|c|c|c|c|c|c|c|c|c|}
\hline \multicolumn{9}{|c|}{ Glycosaminoglycan disaccharides [ $\mu \mathrm{mol} / \mathrm{l}]$} \\
\hline Patients & Hyaluronan & Chondroitin & $\begin{array}{l}\text { Chondroitin- } \\
\text { 4-sulphate }\end{array}$ & $\begin{array}{l}\text { Chondroitin- } \\
\text { 6-sulphate }\end{array}$ & Dermatan & $\begin{array}{l}\text { Dermatan- } \\
\text { 4-sulphate }\end{array}$ & $\begin{array}{l}\text { Dermatan- } \\
\text { 6-sulphate }\end{array}$ & Sum \\
\hline 1 & 0.46 & 12.43 & 3.42 & 0.73 & 0.00 & 0.25 & 0.00 & 17.29 \\
\hline 2 & 0.44 & 8.46 & 1.78 & 0.42 & 0.00 & 0.00 & 0.00 & 11.10 \\
\hline 3 & 0.00 & 12.83 & 11.39 & 0.10 & 0.00 & 1.29 & 0.00 & 25.61 \\
\hline 4 & 0.08 & 7.15 & 7.85 & 0.00 & 0.00 & 1.12 & 0.10 & 16.30 \\
\hline 5 & 1.03 & 7.73 & 2.56 & 0.04 & 0.16 & 1.38 & 0.00 & 12.90 \\
\hline 6 & 1.48 & 12.26 & 2.65 & 0.41 & 0.00 & 0.00 & 0.00 & 16.80 \\
\hline 7 & 0.47 & 10.14 & 1.73 & 0.49 & 0.00 & 0.38 & 0.00 & 13.21 \\
\hline 8 & 0.04 & 13.53 & 8.61 & 0.04 & 0.00 & 1.06 & 0.00 & 23.28 \\
\hline 9 & 0.07 & 9.80 & 9.42 & 0.26 & 0.13 & 0.86 & 0.00 & 20.54 \\
\hline 10 & 0.80 & 9.84 & 3.10 & 0.10 & 0.00 & 1.31 & 0.00 & 15.15 \\
\hline 11 & 0.00 & 4.51 & 7.35 & 0.24 & 0.00 & 0.00 & 0.00 & 12.10 \\
\hline 12 & 0.10 & 3.73 & 2.67 & 0.02 & 0.00 & 0.00 & 0.00 & 6.52 \\
\hline 13 & 0.06 & 4.58 & 3.90 & 0.03 & 0.00 & 0.00 & 0.00 & 8.57 \\
\hline 14 & 0.00 & 1.42 & 1.35 & 0.06 & 0.00 & 0.00 & 0.00 & 2.83 \\
\hline 15 & 0.00 & 3.97 & 5.02 & 0.10 & 0.00 & 0.00 & 0.00 & 9.09 \\
\hline 16 & 0.24 & 9.68 & 2.42 & 0.36 & 0.00 & 0.00 & 0.00 & 12.70 \\
\hline 17 & 0.40 & 10.23 & 2.10 & 0.40 & 0.00 & 0.00 & 0.00 & 13.13 \\
\hline 18 & 0.20 & 12.50 & 12.70 & 0.00 & 0.00 & 1.38 & 0.00 & 26.78 \\
\hline 19 & 0.00 & 10.28 & 11.08 & 0.24 & 0.09 & 1.33 & 0.00 & 23.02 \\
\hline 20 & 0.52 & 7.43 & 2.64 & 0.19 & 0.00 & 0.85 & 0.00 & 11.63 \\
\hline 21 & 0.46 & 12.43 & 3.42 & 0.73 & 0.00 & 0.25 & 0.00 & 17.29 \\
\hline 22 & 0.44 & 8.46 & 1.78 & 0.42 & 0.00 & 0.00 & 0.00 & 11.10 \\
\hline 23 & 0.00 & 12.83 & 11.39 & 0.10 & 0.00 & 1.29 & 0.00 & 25.61 \\
\hline 24 & 0.08 & 7.15 & 7.85 & 0.00 & 0.00 & 1.12 & 0.10 & 16.30 \\
\hline 25 & 1.03 & 7.73 & 2.56 & 0.04 & 0.16 & 1.38 & 0.00 & 12.90 \\
\hline 26 & 1.48 & 12.26 & 2.65 & 0.41 & 0.00 & 0.00 & 0.00 & 16.80 \\
\hline 27 & 0.47 & 10.14 & 1.73 & 0.49 & 0.00 & 0.38 & 0.00 & 13.21 \\
\hline 28 & 0.04 & 13.53 & 8.61 & 0.04 & 0.00 & 1.06 & 0.00 & 23.28 \\
\hline 29 & 0.07 & 9.80 & 9.42 & 0.26 & 0.13 & 0.86 & 0.00 & 20.54 \\
\hline 30 & 0.80 & 9.84 & 3.10 & 0.10 & 0.00 & 1.31 & 0.00 & 15.15 \\
\hline 31 & 0.40 & 11.26 & 2.56 & 0.29 & 0.00 & 0.17 & 0.00 & 14.68 \\
\hline 32 & 0.36 & 11.32 & 3.26 & 0.51 & 0.00 & 0.43 & 0.00 & 15.88 \\
\hline 33 & 0.18 & 13.26 & 11.79 & 0.16 & 0.00 & 1.30 & 0.00 & 26.69 \\
\hline 34 & 0.00 & $5.9 \overline{7}$ & 7.24 & 0.09 & 0.00 & 1.06 & 0.00 & 14.36 \\
\hline 35 & 0.00 & 11.37 & 4.66 & 0.16 & 0.00 & 1.17 & 0.00 & 17.36 \\
\hline 36 & 0.00 & 10.34 & 3.78 & 0.48 & 0.00 & 0.00 & 0.00 & 14.60 \\
\hline 37 & 0.55 & 10.11 & 5.22 & 0.77 & 0.00 & 0.28 & 0.00 & 16.93 \\
\hline 38 & 0.17 & 14.65 & 14.93 & 0.00 & 0.05 & 1.33 & 0.05 & 31.18 \\
\hline 39 & 0.07 & 10.50 & 8.78 & 0.29 & 0.00 & 1.16 & 0.09 & 20.89 \\
\hline 40 & 0.35 & 7.90 & 1.71 & 0.02 & 0.00 & 1.19 & 0.10 & 11.27 \\
\hline 41 & 0.38 & 14.05 & 4.21 & 0.28 & 0.00 & 0.00 & 0.00 & 18.92 \\
\hline 42 & 0.78 & 10.75 & 4.43 & 0.55 & 0.00 & 0.41 & 0.00 & 16.92 \\
\hline 43 & 0.00 & 3.40 & 3.95 & 0.00 & 0.00 & 1.31 & 0.00 & 8.66 \\
\hline 44 & 0.15 & 6.30 & 3.12 & 0.00 & 0.00 & 0.95 & 0.00 & 10.52 \\
\hline 45 & 1.05 & 9.03 & 3.19 & 0.16 & 0.00 & 1.36 & 0.08 & 14.87 \\
\hline 46 & 0.48 & 14.34 & 4.30 & 0.48 & 0.00 & 0.36 & 0.00 & 19.96 \\
\hline 47 & 0.25 & 8.10 & 2.72 & 0.34 & 0.00 & 0.27 & 0.00 & 11.68 \\
\hline 48 & 0.07 & 8.68 & 9.98 & 0.00 & 0.00 & 1.22 & 0.00 & 19.95 \\
\hline 49 & 0.00 & 12.24 & 10.68 & 0.07 & 0.37 & 1.28 & 0.10 & 24.74 \\
\hline 50 & 0.61 & 11.25 & 2.40 & 0.10 & 0.00 & 1.22 & 0.08 & 15.66 \\
\hline 51 & 0.26 & 14.64 & 3.65 & 0.61 & 0.00 & 0.00 & 0.00 & 19.16 \\
\hline 52 & 0.36 & 5.90 & 1.83 & 0.26 & 0.00 & 0.00 & 0.00 & 8.35 \\
\hline 53 & 0.27 & 8.32 & 10.20 & 0.28 & 0.16 & 1.10 & 0.16 & 20.49 \\
\hline 54 & 0.00 & 6.26 & 8.23 & 0.09 & 0.00 & 1.37 & 0.17 & 16.12 \\
\hline 55 & 0.60 & 9.80 & 4.84 & 0.10 & 0.00 & 0.95 & 0.21 & 16.50 \\
\hline$\overline{\mathbf{x}}$ & 0.338 & 9.52 & 5.42 & 0.235 & 0.023 & 0.705 & 0.023 & 16.31 \\
\hline $\mathbf{s}$ & 0.364 & 3.09 & 3.53 & 0.211 & 0.065 & 0.552 & 0.049 & \\
\hline
\end{tabular}


Dermatan-4-sulphate disaccharides were found in concentrations up to $0.81 \mu \mathrm{mol} / 1$ serum. Dupuoy et al. (16) determined 0 to $2 \mathrm{mg} / \mathrm{l}$ for the reference value of polymeric dermatan sulphate in human plasma. The principle of the assay is the measurement of residual amidolytic thrombin activity after incubation with heparin cofactor II in defibrinated plasma; dermatan sulphate accelerates thrombin inhibition by heparin cofactor.

For hyaluronan the reference value has been reported between 10 and $100 \mu \mathrm{g} / \mathrm{l}$ serum $(17,18)$. In the present study, the mean serum concentrations of hyaluronan disaccharides were $0.26 \mu \mathrm{mol} / \mathrm{l}(\mathrm{men})$ and $0.34 \mu \mathrm{mol} / 1$ (women).

When these results are converted from $\mu \mathrm{mol}$ disaccharides into $\mu \mathrm{g}$ polymeric glycosaminoglycans, they are in accordance with the reference values.

Serum was preferred, although plasma could also be used $(19,20)$. In practice, the isolation of glycosaminoglycans from serum was shorter and less demanding. With both methods the isolation of glycosaminoglycans was quantitative.

Total glycosaminoglycan concentrations show good agreement with the results of Larking (2) and Strapans et al. (5).

\section{References}

1. Poulson, J. H. (1975) Urine and tissue glycosaminoglycans and their interactions. Dan. Med. Bull. 33, 75-96.

2. Larking, P. W. (1987) Quantitative gas chromatographic measurement of glycosaminoglycan hexosamines in urine and plasma. J. Chromatogr. 420, 231-239.

3. Kodama, C., Ototani, N., Isemura, M., Aikawa, J. \& Yosizawa, Z. (1984) High-performance liquid chromatography of pyridylamino derivatives of unsaturated disaccharides produced from chondroitin sulfated isomers by chondroitinases. J. Biochem. (Tokyo) 96, 1283-1287.

4. Saito, H., Yamagata, T. \& Susuzi, S. (1968) Enzymatic methods for the determination of small quantites of isomeric chondroitin sulfates. J. Biol. Chem. 243, 1536-1542.

5. Staprans, I. \& Felts, J. M. (1985) Isolation and characterization of glycosaminoglycans in human plasma. J. Clin. Inv. Inc. 76, 1984-1991.

6. Kosakai, M. \& Yosizawa, Z. (1979) A Partial Modification of the Carbazole Method of Bitter and Muir for Quantitation of Hexuronic acids. Anal. Biochem. 93, 295-298.

7. Farndale, R. W., Sayers, C. A. \& Barrett, A. J. (1986) Improved quantitation and discrimination of sulfated glycosaminoglycans by use of dimethylmethylene blue. Biochim. Biophys. Acta 883, 173-177.

8. Gurr, E., Pallasch, G., Tunn, S., Tamm, C. \& Delbrück, A. (1985) High performance liquid chromatographic assay of disaccharides and oligosaccharides produced by the digestion of glycosaminoglycans with chondroitin sulphate lyases. J. Clin. Chem. Clin. Biochem. 23, 77-87.

\section{Conclusions}

The presented method quantifies glycosaminoglycans in human serum or plasma as disaccharides. Applying this high specific and sensitive' method, quantitative results can be obtained with good precision, accuracy and performance. This HPLC method can therefore be considered as a candidate reference method. Furthermore, it allows the detection of the distribution patterns of the glycosaminoglycans, thereby providing a useful tool for elucidating aspects of the biosynthesis and degradation of proteoglycans.

Changes of plasma/serum glycosaminoglycan concentrations have been demonstrated in physiological and pathological conditions $(11-13)$. Therefore in clinical practice the method could lead to a better understanding of glycosaminoglycan involvement in disease.

\section{Acknowledgement}

We thank Miss $M$. Arlart for her skilful technical assistance. This work contains parts of the biochemistry graduation theses of $N$. Janzen and C. Reißner.
9. Hjerpe, A., Antonopoulos, C. A. \& Engfeldt, B. (1982) Determination of hyaluronic acid using high-performance liquid chromatography of chondroitinase digests. J. Chromatogr. $245,365-368$.

10. Larking, P. W. (1989) Total glycosaminoglycans in the plasma of adults: effects of age and gender, and relationship to plasma lipids: A preliminary study. Biochem. Med. Metab. Biol. 42, 192-197.

11. Friman, C., Juvani, M. \& Skrifvars, B. (1977) Acid glycosaminoglycans in plasma II. Findings in rheumatoid arthritis. Scand. J. Rheumatol. 6, 177-182.

12. Friman, C., Nordström, D. \& Eronen, I. (1987) Plasma glycosaminoglycans in systemic lupus erythematodes. J. Rheumatol. 14, 1132-1134.

13. Ferlazzo, A. M., Vinci, R., Muraca, U., Ferlazzo, A. \& Calatroni, A. (1991) Suggestions arising from plasma GAG level changes in human and animal subjects. Ital. Biochem. Soc. Trans. 2, 242.

14. Gysen, P. \& Franchimont, P. (1984) Radioimmunoassay of proteoglycans. J. Immunoassay 5, 221-243.

15. Silvestro, L., Viano, I., Torri, G., Da Col, R. \& Baiocchi, C. (1992) High-performance liquid chromatographic-mass spectrometric analysis of oligosaccharides from enzymatic digestion of glycosaminoglycans. J. Chromatogr. 591, 225232.

16. Dupuoy, D., Sié, P., Dol, F. \& Boneau, B. (1988) A simple method to measure dermatan sulfate at sub-microgram concentrations in plasma. Thromb. Haemost. 60, 236239.

Eur. J. Clin. Chem. Clin. Biochem. / Vol. 31, 1993 / No. 8 
17. Engstroem, L. A., Laurent, U. B., Lilja, K. \& Laurent, T. C. (1985) Concentration of sodium hyaluronate in serum. Scand. J. Clin. Lab. Invest. 45, 497-504.

18. Chichibu, K., Matsuura, T., Shichijo, S. \& Yokoyama, M. M. (1989) Assay of serum hyaluronic acid in clinical application. Clin. Chim. Acta 181, 317-324.
19. Janzen, N. (1992) Glykosaminoglykan-Nachweis in verschiedenen Körperflüssigkeiten des Menschen - Pathobiochumische Bedeutung. Graduation Biochemistry, University of Hannover.

20. Reißner, C. (1992) Nachiveis von Glykosaminoglykanen in humanem Blut. Graduation Biochemistry, University of Hannover.

Dr. N. Gässler

Central Laboratory

Caritas Trägergesellschaft Trier e. V.

Hospital St. Elisabeth

Koblenzer Straße 91

D-55516 Wittlich

Germany 
